\title{
Perbaikan Visibilitas pada Citra Berkabut Kawah Gunung Berapi Kelud Menggunakan Color Attenuation Prior
}

\author{
Oddy Virgantara Putra*, Muhammad Firdaus, Shoffin Nahwa Utama \\ Sains dan Teknologi, Teknik Informatika, Universitas Darussalam Gontor, Ponorogo, Indonesia \\ Email: 1,*0ddy@unida.gontor.ac.id, ${ }^{2}$ muhammad.firdaus@unida.gontor.ac.id, ${ }^{3}$ shoffin@ unida.gontor.ac.id \\ Email Penulis Korespondensi: oddy@unida.gontor.ac.id
}

\begin{abstract}
Abstrak-Gunung Kelud merupakan salah satu gunung berapi yang pernah meletus pada tahun 2014. Untuk mengamati aktivitas, telah dipasang CCTV daerah puncak kawah gunung Kelud. Kawah gunung Kelud mengeluarkan gas-gas yang berasal dari dasar kawah. Gas tersebut membuat pengawasan CCTV menjadi tidak terganggu sehingga citra yang dihasilkan akan memiliki noise. Dengan dehazing, citra dapat memperbaiki sehingga citra yang dihasilkan dapat dilihat dengan jelas. Metode yang digunakan untuk operasi ini yaitu Color Attenuation Prior. Pada tahapan awal, ada proses dark channel yang berfungsi untuk mengubah piksel yang memiliki intensitas rendah menjadi gelap. Tahap kedua adalah dengan mengestimasi cahaya atmosfer dari citra dark channel. Proses ini hampir beriringan dengan estimasi peta kedalaman. Langkah keempat adalah estimasi peta transmisi yang berfungsi mentransmisi piksel berintensitas rendah ke piksel berintensitas tinggi. Yang terakhir scene radiance recovery. Hasil penelitian menunjukan bahwa citra berkabut berhasil dan menghilangkan efek kabut sehingga memperjelas visibilitas dari citra. Hasil kuesioner menunjukkan sentimen positif dengan hasil baik sebanyak $80 \%$ dari total responden. Penelitian selanjutnya agar dapat diaplikasikan secara langsung atau real time.
\end{abstract}

Kata Kunci: Color Attenuation; Dark Channel; Dehazing; Kabut; Gunung Berapi

Abstract-Mount Kelud is one of the volcanoes that erupted in 2014. To observe the activity, CCTV has been installed in the crater peak of Mount Kelud. The crater of Mount Kelud emits gases coming from the bottom of the crater. The gas makes CCTV surveillance undisturbed so that the resulting image will have noise. By using dehazing, visibility can be improved so that the resulting image can be seen clearly. The method used for this operation is Color Attenuation Prior. In the early stages, there is a dark channel process that works to turn low-intensity pixels dark. The second step is to estimate the atmospheric light from the dark channel image. This process is almost in parallel with the estimation of the depth map. The fourth step is estimating the transmission map, which functions to transmit low-intensity pixels to high-intensity pixels. The last one is the radiance recovery scene. The results show that the foggy image is successful, and it eliminates the fog effect, thus enhancing the visibility of the image. And from questionnaire results, we got $80 \%$ positive results from all respondents. Further research so that it can be applied directly or in real-time.

Keywords: Color Attenuation; Dark Channel; Dehazing; Haze; Volcano

\section{PENDAHULUAN}

Indonesia merupakan negara yang memiliki 129 gunung berapi aktif. Gunung Kelud merupakan salah satu gunung berapi aktif yang pernah meletus beberapa kali. Salah satu nya yaitu pada tahun 2014 silam. Meletusnya gunung Kelud pada tahun 2014 merupakan letusan terbesar sepanjang sejarah meletusnya gunung Kelud. Karena kejadian tersebut, CCTV yang berada pada puncak gunung Kelud mengalami kerusakan.

CCTV yang terletak di puncak gunung Kelud digunakan untuk memantau aktivitas gunung Kelud, yaitu dengan mengamati kawah gunung Kelud. Menurut [1], kegiatan yang dilakukan yaitu pengamatan secara visual dan non-visual secara jarak jauh daerah sekitar permukaan kawah, batu-batuan dan pepohonan di sekitar kawah.

Salah satu aktivitas yang dipantau oleh CCTV tersebut yaitu aktivitas asap atau gas sebelum terjadinya erupsi. Hal itu merupakan aktivitas tertinggi dari kawah gunung Kelud. Gas tersebut muncul dari dasar kawah gunung Kelud. Gas yang terdiri dari $\mathrm{SO} 2, \mathrm{HC} 1, \mathrm{HF}$ dan $\mathrm{CO} 2$ cukup kuat menembus permukaan kawah gunung Kelud sehingga membentuk asap. Asap tersebut akan menyelimuti kawah gunung kelud. Hal itu membuat CCTV di puncak gunung kelud terganggu dalam mengamati kawah gunung kelud. CCTV akan menghasilkan citra kawah gunung Kelud yang memiliki noise. Noise tersebut merupakan kabut yang menyelimuti kawah gunung kelud. Hal tersebut sangat mengganggu pengawasan dan pengamatan aktivitas kawah gunung Kelud. Untuk mengatasi adanya noise tersebut dalam citra, dilakukanlah proses dehazing untuk menghilangkan noise tersebut dalam citra.

Kabut merupakan sebuah fenomena yang terjadi karena adanya butiran air yang berasal dari uap air yang mengalami proses pengembunan yang terjadi di atas permukaan bumi. Proses pengembunan terjadi ribuan meter di atas permukaan bumi, maka butiran tersebut akan berubah menjadi awan. Dalam website KBBI, diartikan bahwa kabut merupakan uap air hasil dari kondensasi yang masih dekat dengan tanah terjadi karena adanya peristiwa pemanasan atau pendinginan udara, hal tersebut yang biasa menyebabkan berkurangnya jarak pandang di permukaan bumi.

Menurut [2]-[4], kabut dan asap mengarah ke rendahnya penglihatan karena partikel-partikel tersebut akan memecah dan menyebarkan sinar. Salah satu penyebab terjadinya kabut disebabkan adanya partikelpartikel atmosfer yang berkumpul di udara. Di daerah perindustrian biasanya sering terjadi fenomena tersebut. Hal itu disebabkan banyaknya polusi udara di area perindustrian. Menurut [5]-[7], pengambilan foto di luar ruangan akan mengalami penurunan kualitas jika dalam kondisi cuaca yang sedang buruk. 


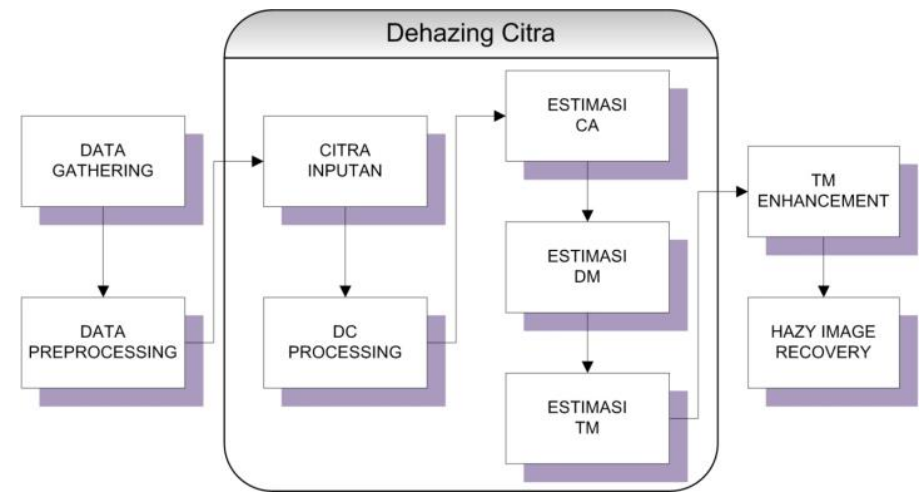

Gambar 1. Diagram Alur dari tahapan penelitian dehazing

Sebagian besar, pemandangan danau dalam citra dipengaruhi oleh lingkungannya. Hal ini disebabkan oleh pancaran sinar dari langit yang langsung menyinari tanaman dan daratan di sekitar danau kemudian dipantulkan dan diserap oleh partikel kabut. Airlight memainkan peran besar dalam dehazing, terutama dark channel prior (DCP). Dalam kasus kami, tampilan kamera tidak menutupi area langit.

Dalam beberapa tahun terakhir, sejumlah penelitian telah dikembangkan untuk mengatasi dehazing. Tan's dkk[8], meneliti tentang bagaimana mengembalikan visibilitas citra pada cuaca buruk dan menghasilkan citra yang jernih. Warna asli tidak dikembalikan. Sayangnya, metode ini cenderung menghasilkan kontras terlalu tinggi. Fattal [9] menyempurnakan model citra dengan memecahnya menjadi beberapa wilayah dan menggunakan Independent Component Analysis (ICA) untuk memulihkan citra tersebut. Namun, metodenya mungkin gagal pada kabut dengan tingkat kepadatan yang tinggi dan membutuhkan waktu lama untuk pemrosesan.

Dengan asumsi dari pengamatan kami, pada sebagian besar patch citra, setidaknya terdapat satu channel warna dalam ruang bidang RGB, memiliki intensitas yang rendah dan hampir mendekati nol. Inilah yang disebut dengan DCP yang diperkenalkan oleh He dkk [3]. Namun, pada tepi citra yang dipulihkan, terdapat blok-blok. Blok ini dihaluskan menggunakan algoritma Soft-Matting (SM). SM memang dikenal memakan proses yang sangat lama. Akhirnya, pada tahun berikutnya, He dkk [10] juga mengenalkan filter dengan menggunakan citra sebagai pemandu dalam filter pasca dehazing. Metode DCP juga memiliki kekurangan yaitu adanya saturasi yang berlebih jika terdapat objek yang lebih terang dari cahaya atmosfer (CA).

Zhu dkk [4] mengusulkan model kedalaman dari citra luar ruangan yang dibangun dari asumsi hubungan antara kecerahan dengan saturasi. Hubungan keduanya ini ternyata berkorelasi positif. Model ini disebut selanjutnya dinamakan dengan Color Attenuation Prior (CAP).

Dalam kebutuhan selanjutnya, tidak hanya proses penghilangan kabut yang sangat penting dalam hal restorasi visibilitas tetapi juga restorasi warna dan video dehazing. Algoritma berbasis video untuk dehazing diusulkan oleh Kim dkk [11]. CAdiestimasi dengan metode pembagian citra yang disebut dengan quad-tree subdivision. Proses ini membagi citramenjadi empat bagian secara rekursif. Proses ini berlangsung hingga proses rekursi mencapai ambang tertentu. Metode ini cukup efektif untuk mencari CA dari citra outdoor (CO).

Pada penelitian ini, metode dehazing yang digunakan yaitu Color Attenuation Prior. Color attenuation prior mengembalikan informasi kedalaman peta (DM) pada citra, sehingga mempermudah dalam menghapus dan menghilangkan kabut dari citra kabut tunggal.

\section{METODOLOGI PENELITIAN}

Pada bagian ini, dijelaskan beberapa tahap dalam penelitian yaitu: Pengumpulan Data, Analisis Sampel, Penerapan Metode yang diusulkan, dan Evaluasi. Semua tahapan di bawah ini diilustrasikan seperti pada Error! Reference source not found.

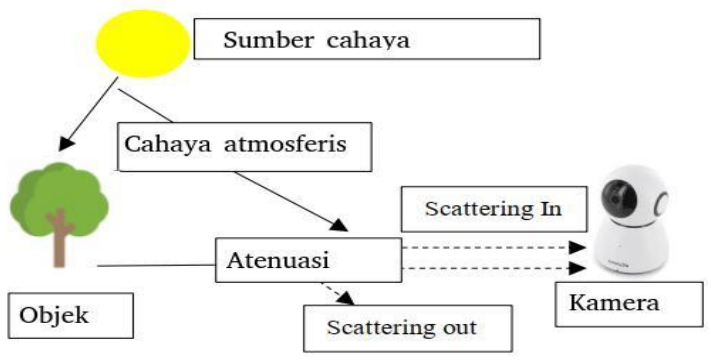

Gambar 2. Model akuisisi CO

Oddy Virgantara Putra, Copyright (C2021, MIB, Page 225 


\subsection{Pengumpulan Data}

Dataset citra berkabut diambil dari citra hasil snapshot kamera CCTV milik Pusat Vulkanologi dan Mitigasi Bencana Geologi (PVMBG) Gunung Kelud di kabupaten Kediri, Jawa Timur. Citra kawah di capture setiap sepuluh menit. Sedangkan untuk waktu pengambilan citra, kami menentukan waktunya sekitar pukul $06.00 \mathrm{WIB}$ hingga 17.00 WIB dikarenakan kondisi pencahayaan yang cukup optimal hanya didapat pada waktu itu.

\subsection{Analisis Sampel}

Dataset citra kawah Kelud berukuran 800 x 450 piksel dengan format JPG. Sebelum dilakukan dehazing, citra di-crop terlebih dahulu karena di bagian atas citra terdapat data catatan waktu kapan citra diambil dengan latar belakang putih. Latar belakang ini mengganggu proses dehazing terutama saat estimasi CA.

\subsection{Penerapan Metode Adaptive Color Attenuation Prior}

Di subbagian ini dibahas semua tahapan dari metode usulan, yaitu: Pemodelan Citra Kabut, Color Attenuation, Estimasi CA, Estimasi DM, Estimasi PT, dan yang terakhir adalah Pemulihan Citra.

\subsubsection{Pemodelan Citra Kabut}

Proses akuisisi CO, terjadi dimulai dari adanya sumber cahaya yang menyinari objek jauh seperti pohon, dahan, bukit, dan lainnya. Warna objek yang jauh ini berpropagasi melalui partikel-partikel air di udara. Dikarenakan jarak yang jauh serta adanya kabut, maka warna asli dihamburkan (scattering) oleh partikel air. Sehingga, warna objek yang diterima oleh kamera tidak seperti warna aslinya. Proses perubahan warna asli oleh kabut dinamakan dengan atenuasi. Proses ini diilustrasikan sebagaimana pada Error! Reference source not found.. Adapun secara matematis, $\mathrm{CO}$ umumnya dimodelkan seperti pada (1):

$$
I_{k}(a)=J_{k}(a) t(a)+A(1-t(a))
$$

dimana aposisi koordinat dalam piksel dalam citra, $k$ adalah saluran warna RGB, $I$ adalah citra berkabut, $J$ adalah citra yang dipulihkan dari kabut, tadalah peta transmisi (PT), A adalah CA, danaadalah koordinat sumbu pada citra. Ketika kondisi atmosfer homogen, PT dimodelkan sebagai (2):

$$
t(a)=e^{-\beta d(a)}
$$

di mana $\beta$ adalah koefisien hamburan cahaya oleh partikel air di udara. Dikarenakan kondisi homogen, maka nilai koefisien ini adalah 1 [12]. Simbol $d$ adalah DM. Nilai $t$ ini disesuaikan seperti pada (3):

$$
0 \leq t(a) \leq 1
$$

\subsubsection{Color Attenuation}

Dalam pemandangan berkabut, sebuah objek yang jauh dari pengamat terpisah oleh jarak yang bermil-mil jauhnya. Kondisi ini menyebabkan informasi dari DM yang terlalu besar. Maka, perlu pendekatan estimasi untuk mengetahui nilai dari DM. Pemulihan citra dari berkabut menjadi cerah menjadi cukup menantang. Hal ini disebabkan karena minimnya informasi. Secara prinsip, mata manusia dapat membedakan dengan jelas antara kabut dan objek yang ada di alam. Terinspirasi oleh [4], kami menemukan bahwa jarak objek ke kamera dengan kecerahan dan saturasi pemandangan alam berkorelasi secara positif.

Sebagai ilustrasi (lihat Error! Reference source not found.) korelasi positif pada citra dua dimensi outdoor, diambil tiga sampel sub-citra dengan ukuran, misalnya, 15 x 15 piksel. Sub-citra pertama (C1) di-crop pada jarak yang dekat, sub-citra kedua (C2) pada jarak menengah, dan sub-citra ketiga (C3) pada jarak yang jauh. Ternyata, setelah diamati dengan domain warna HSV, ketiga sub-citra ini memiliki ciri-ciri unik. Pada C1, nilai saturasi (S) paling tinggi dibanding C2 dan C3. Sedangkan nilai kecerahan (V) paling rendah diantara semua sub-citra. Kondisi perbedaan $\mathrm{S}$ dan $\mathrm{V}$ pada $\mathrm{C} 2$ tidak terlalu signifikan atau bahkan hampir sama. Sedangkan C3 nilai S dan V berbanding terbalik dengan C1. Jika dimodelkan secara matematis, maka diperoleh (4):

$$
d \propto h \propto v-s
$$

di mana $h$ adalah kepadatan kabut pada citra, $v$ adalah kecerahan atau brightness, dan $s$ adalah saturasi. Korelasi positif dan proporsionalitas dari elemen DM, $s, v$, dan $h$ inilah yang dinamakan dengan CAP.

\subsubsection{Estimasi CA}

Pada tahapan ini, kami menerapkan teknik akuisisi CA dari metode DCP. Menurut [3], [13], [14], DCP didefinisikan sebagai pixel yang memiliki intensitas rendah dalam salah satu kanal warna RGB citra tersebut. Apabila terdapat suatu citra yang memiliki intensitas rendah di dalam salah satu saluran warna RGB, maka citra tersebut memiliki dark channel di dalamnya.

Nilai $A$ dari persamaan (1) diperoleh dengan mengambil beberapa nilai intensitas tertinggi dari citra DC sebesar $0.1 \%$. Selanjutnya, hasil dari CA ini dipakai untuk tahapan terakhir dari dehazing. 


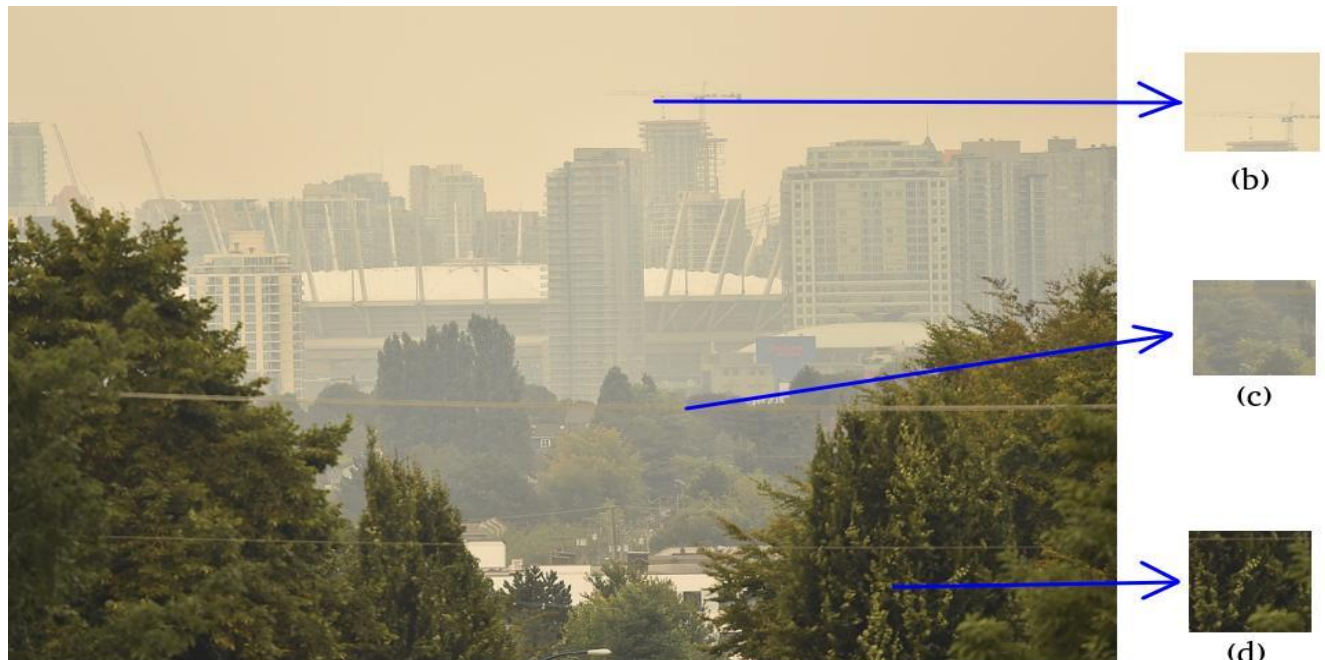

(a)

Gambar 3. Korelasi antara kabut dan jarak benda. (a) citra kabut asli, (b) - (d) potongan citra pada jarak yang jauh, sedang, dan dekat.

\subsubsection{Estimasi DM}

DCP menggunakan persamaan (5) untuk mencari nilai $t$ :

$$
t(a)=1-\omega \min _{y \in w(a)}\left(\min _{k} \frac{I_{k}(n)}{A_{k}}\right)
$$

di manawadalah konstata yang digunakan agar menjaga kabut agar nampak alami. Adapun besarannya adalah 0,95 .

Tahapan ini berfungsi untuk menghitung nilai dari intensitas DM. Dengan asumsi CAP, maka untuk mendapatkan nilai $d$ dari persamaan (2), dilakukan dengan pendekatan regresi linier seperti pada (6):

$$
d(a)=\theta_{1}+\theta_{2} v(a)+\theta_{3} s(a)
$$

di mana $\theta_{1}, \theta_{2}, \theta_{3}$ adalah koefisien yang akan diestimasi. Untuk memudahkan perhitungan parameter tersebut, didefinisikan matriks $\mathbf{K}$, vektor $\mathbf{p}$, danvektor $\mathbf{d}$. Di mana:

$$
K=\left[\begin{array}{ccc}
1 & v_{0} & s_{0} \\
1 & v_{1} & s_{1} \\
1 & \vdots & \vdots \\
1 & v_{n} & s_{n}
\end{array}\right], p=\left[\begin{array}{c}
\theta_{1} \\
\theta_{2} \\
\theta_{3}
\end{array}\right], d=\left[\begin{array}{c}
d_{1} \\
d_{2} \\
\vdots \\
d_{n}
\end{array}\right]
$$

dengan mengombinasikan persamaan (6) dan (7) maka diperoleh (8):

$$
p=\left(K^{T} K\right)^{-1} K^{T} d
$$

\subsubsection{Estimasi PT}

Setelah DM diperoleh dari persamaan (8), maka nilai PT bisa diperoleh dari persamaan (2). Akan tetapi, untuk meningkatkan kualitas $t$, pada penelitian ini menerapkan metode koreksi gamma. Sehingga diperoleh (9):

$$
t_{v}(a)=v_{\max }\left(\frac{t(a)}{v_{\max }}\right)^{\gamma}
$$

di mana nilai $\gamma$ diperoleh dari (10), yaitu:

$$
\gamma=\left\{\begin{array}{cc}
1+\frac{z}{T} & , z \geq T \\
1 & , z<T
\end{array}\right\}
$$

$t_{v}$ adalah $t$ yang sudah ditingkatkan kualitasnya, $v_{\max }$ adalah nilai intensitas maksimal dari $t$, sedangkan $\gamma$ adalah nilai gamma, $T$ adalah nilai ambang batas dari $t$.

\subsubsection{Pemulihan Citra}

Ini adalah tahapan terakhir dari proses dehazing. Tujuan utama dari dehazing adalah mengekstrak nilai $\mathbf{J}$ pada persamaan (1). Dari sini, diperoleh nilai J dari (11):

$$
J_{k}(a)=A_{k}+\frac{I_{k}(a)-A_{k}}{t_{k}(a)}
$$

\subsection{Pengujian}

Pada tahap pengujian, kami menyebarkan kuesioner kepada 10 responden untuk mengevaluasi secara visual. 


\section{HASIL DAN PEMBAHASAN}

Pada bagian ini, beberapa algoritma diuji dengan dataset citra kabut yang umum seperti labu dan kerumunan orang. Tujuan pengujian ini adalah untuk mengetahui performa metode ini dibandingkan metode dehazing sebelumnya. Pada bagian ini performa metode yang diusulkan dievaluasi dengan membandingkannya dengan 4 algoritma dehazing sebelumnya. Salah satunya adalah algoritma dehazing yang paling 228opular, DCP yang diusulkan oleh He [15], yang kedua didasarkan pada DCP adaptif [15], yang ketiga dari [16], dan yang terakhir satu dari [17]. Mari kita sebut empat algoritme dengan He (DCP), Meng (ADCP), Tarel (TAR), dan dari Chen untuk High-Speed Gain Intervention Refinement (HGIR). Percobaan dilakukan menggunakan Laptop ASUS ROG GL503GE dengan memori RAM 16 GB, PCIe G3x4 SSD, prosesor Intel Core i7-8750H, dan NVIDIA GTX1050Ti v4G.

Langkah pertama mengambil citra dari rekaman CCTV kawah gunung Kelud. Citra ini adalah citra RGB berukuran 800 x 450 piksel. Citra kawah di-capture setiap 1 menit. Tahap selanjutnya adalah persiapan prosedur dehazing. Langkah pertama adalah mengambil DC dari setiap citra. Dari DC ini, dipilih piksel kecerahan $0,1 \%$ tertinggi.

\subsection{Tahapan Pemulihan Citra Kabut}

Pada bagian ini, sebelum dilakukan dehazing, citra harus melalui tahapan preprocessing seperti cropping. Citra hanya di-crop bagian atas saja dengan ukuran crop 800 x 440. Jadi, terdapat pengurangan sebesar 10 piksel.

\subsubsection{Implementasi DC}

Di tahap ini, citra kabut diproses dalam ranah spasial dengan teknik DC. Teknik ini dinilai cukup efektif dalam proses sortir piksel-piksel gelap dari citra RGB. Untuk memulai DC, pertama kali adalah dengan membuat patch kecil dengan ukuran 15 x 15 piksel. Dari patch ini, dihitung secara konvolusi pada citra inputan. Citra DC berbeda dengan citra grayscale. Jika citra grayscale diperoleh dengan menghitung nilai rata-rata intensitas RGB, maka citra DC dihitung dengan mendapatkan nilai intensitas terendah dari salah satu saluran RGB. Luaran dari citra ini bisa dilihat pada Gambar 4 (b).

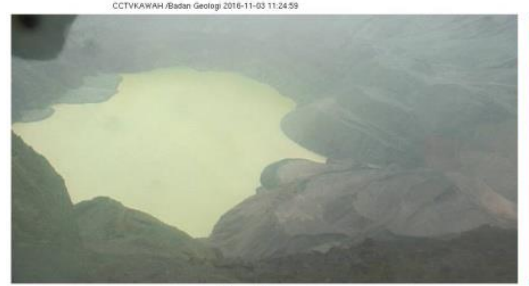

(a)

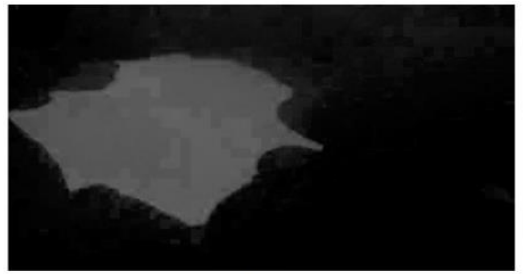

(d)

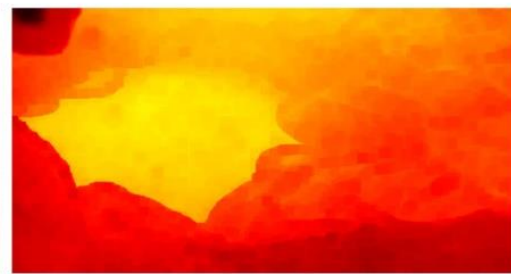

(b)

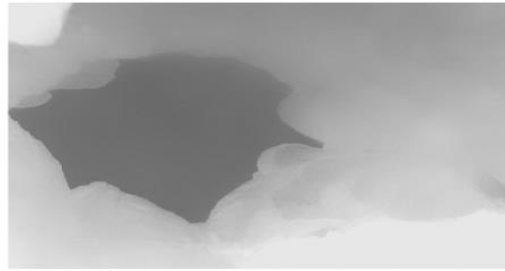

(e)

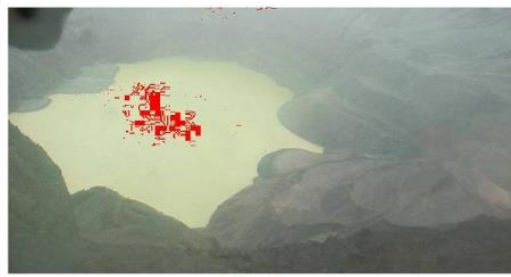

(c)

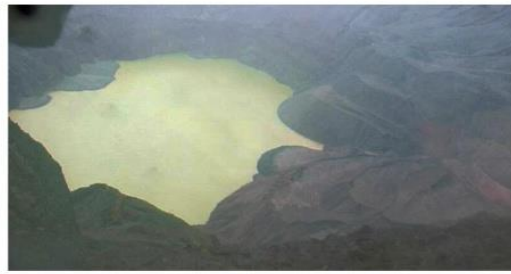

(f)

Gambar 4. Contoh citra kabut dari Kelud. (a) Citra berkabut hasil tangkapan CCTV, (b) citra DC, (c) adalah citra CA, (d) adalah DM, (e) adalah PT yang sudah ditingkatkan, dan (f) adalah hasil pemulihan citra.

\subsubsection{Estimasi CA dari DC}

Dalam citra DC, piksel-piksel dengan intensitas tinggi yang hampir mendekati putih dianggap sebagai CA. CA ini diperoleh dengan mencari $0,1 \%$ piksel-piksel dengan intensitas tertinggi. Luaran dari CA adalah bentuk data vektor. Hasil CA dari DC bisa dilihat di Gambar 4 (c)

\subsubsection{Estimasi PT}

Pada bagian ini, metode yang diusulkan (ACAP) disimulasikan menggunakan data yang dihasilkan yang diperoleh dari Google. Metode ini dibandingkan dengan metode dehazing sebelumnya. Guided Image Filtering (GIF) [10] juga diimplementasikan untuk memperhalus hasil yang mengandung blok-blok. Ketika CA diestimasi, nilai PT juga dihitung secara terpisah. Seperti dalam persamaan (2), $t$ bergantung pada DM. 
JURNAL MEDIA INFORMATIKA BUDIDARMA

Volume 5, Nomor 1, Januari 2021, Page 224-232

ISSN 2614-5278 (media cetak), ISSN 2548-8368 (media online)

Available Online at https://ejurnal.stmik-budidarma.ac.id/index.php/mib

DOI 10.30865/mib.v5i1.2637

Intensitasd diperkirakan dari persamaan (5) menggunakan matriks pseudo-inverse. Hasil dari pelatihan ini adalah koefisien parameter $\theta_{1}=0,091, \theta_{2}=0.696, \theta_{3}=0,7198$.

He dkk. Menggunakan persamaan (5) untuk memperkirakan peta transmisi. Namun, $t$ yang dihasilkan dapat menyebabkan citra terlalu saturasi (lihat Gambar 10 (b) (1)). Chen [17] mengusulkan estimasi menggunakan filter HGIR yang diperoleh dari perhitungan perbedaan intensitas pada DC dan channel minimum untuk setiap piksel dan kemudian membaginya dengan jumlah total piksel di DC. Alih-alih menggunakan asumsi estimasi $t$ yang digunakan untuk estimasi DM, $t$ langsung diestimasi menggunakan persamaan (2). Koefisien hamburan partikel air di udara $\beta$ dapat diabaikan yang dikarenakan kondisi atmosfer yang homogen. Langkah akhir dari metode CAP adalah pemulihan scene radiance. Karena kita memiliki atm light a dan peta transmisi tmap, ada satu langkah terakhir yang harus dilakukan sebelum tugas akhir. Gambar yang dipulihkan, saat menggunakan $t$ tanpa koreksi gamma (GC), masih belum sepenuhnya memuaskan. Warna dasar danau selalu dipengaruhi oleh warna global, seperti biru saat kabut lebih tebal. Oleh karena itu, warna asli dari tanah sekitar danau terganggu. Warna luminansi danau kemudian ditingkatkan dengan menggunakan teknik peningkatan kualitas warna yang cukup populer yang disebut GC. Nilai gamma untuk citra yang biasa, nilainya adalah satu. Biasanya, untuk citra luar ruangan keabuan, warna luminansi akan meningkat bila nilainya lebih rendah dari satu. Begitu pula sebaliknya. Jadi, untuk meningkatkan luminans, nilai gamma harus lebih tinggi dari satu. Nilai gamma dibatasi demi mencegah terjadinya citra yang over-saturated, yang disebabkan oleh warna danau yang berintensitas tinggi (seperti yang dapat kita lihat pada Gambar 10).

ADCP digunakan daripada mengatur nilai gamma secara adaptif. Dalam penelitian sebelumnya [18], sebelum penggabungan antara DCP dengan GC, proses dehazing hanya bergantung pada pemulihan citra kabut tanpa peningkatkan kontras. Oleh karena itu, warna dari citra yang dipulihkan masih tetap dipengaruhi oleh luminansi global. Luminansi adalah salah satu kekurangan CAP. Untuk mempertahankan atau bahkan memperkuat $t_{v}$, kita harus menemukan rata-rata setiap piksel dalam channel RGB. Perhitungan ini bisa dicari dengan menggunakan persamaan (9). Perhitungan rata-rata ini mampu mendistribusikan warna dengan menyempurnakannya dengan DCP dan GC. Dengan berjalannya semua tahapan, makacitra J bisa dipulihkan dengan menggunakan persamaan (11).

\subsubsection{Hasil Pemulihan Citra (SR)}

Semua tahapan dehazing telah terpenuhi kecuali tahap ini. Sebenarnya, kunci utama keberhasilan tahap SR terletak di PT. Maka, dalam salah satu tahapan metode yang diusulkan terdapat langkah peningkatan PT. Untuk mendapatkan SR, nilai PT yang diperoleh diproses dalam persamaan (11). Sehingga, hasil SR bisa dilihat pada Gambar 4 (f)

\subsection{Hasil Simulasi dengan Dataset Umum}

Pada bagian ini, metode yang diusulkan disimulasikan bersama dengan algoritma lain Tarel [16], He dkk. Untuk DCP dengan GIF [3], [19], Meng untuk Adaptif DCP [15], Chen dkk. untuk HGIR yang dibangun berdasarkan DCP [17] untuk berbagai citra luar ruangan. Citra luar ruangan yang tanpa kabut harus memiliki persyaratan khusus, yaitu: konsistensi warna, konten yang bebas dari blok-blok, dan efek halo.

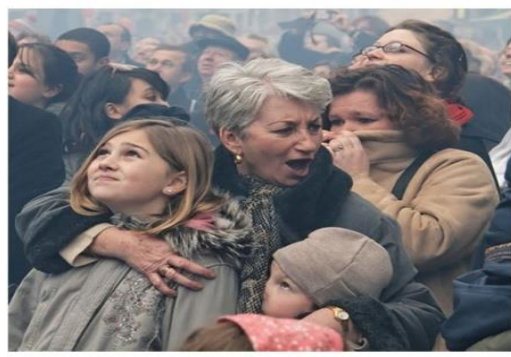

(a)

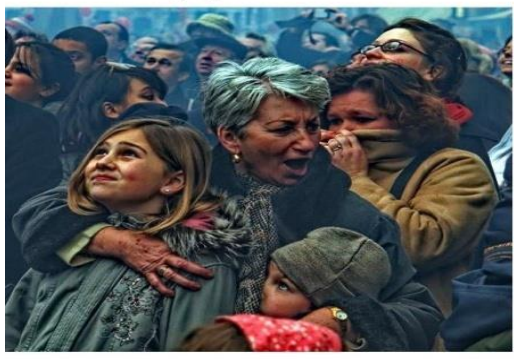

(d)

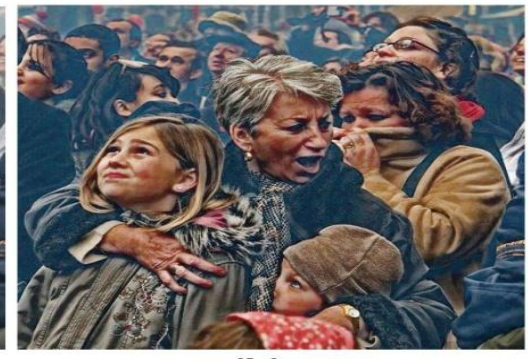

(b)

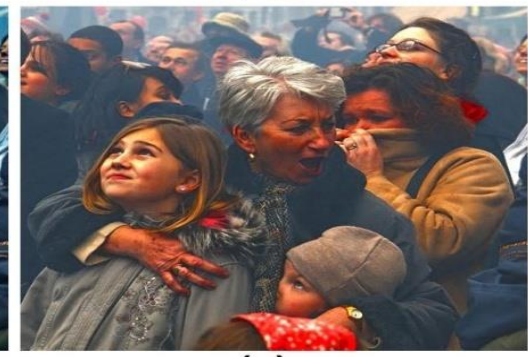

(e)

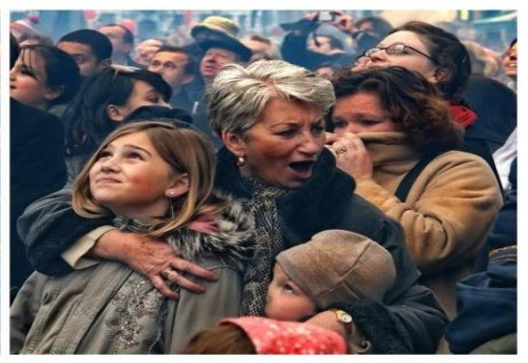

(c)

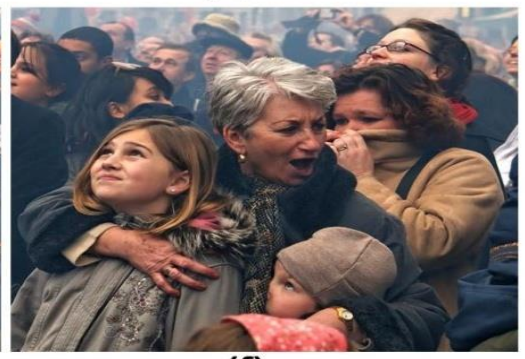

(f)

Gambar 5 Hasil Pemulihan Citra Berkabut Kerumunan Orang dengan beragam metode dehazing. (a) citra inputan berkabut, (b) TAR, (c) DCP, (d) ADCP, (e) HGIR, (f) ACAP. 


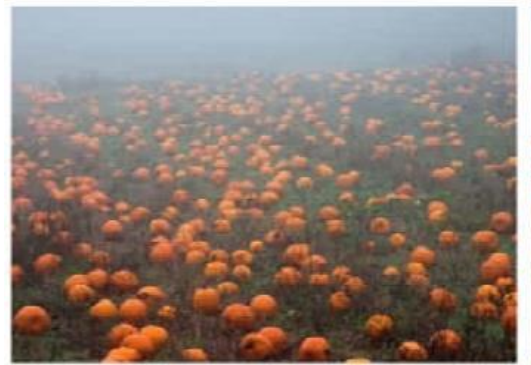

(a)

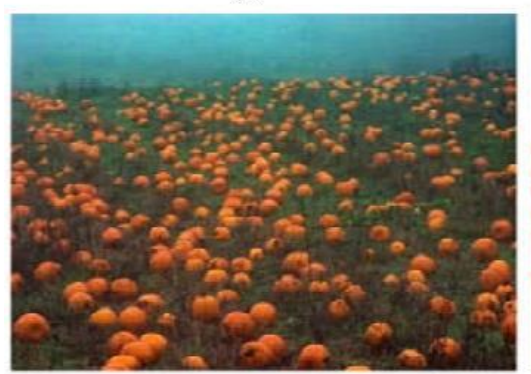

(d)

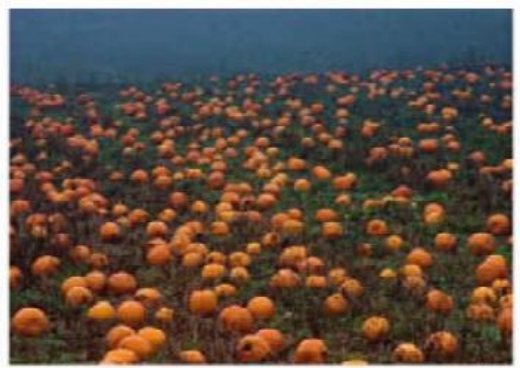

(b)

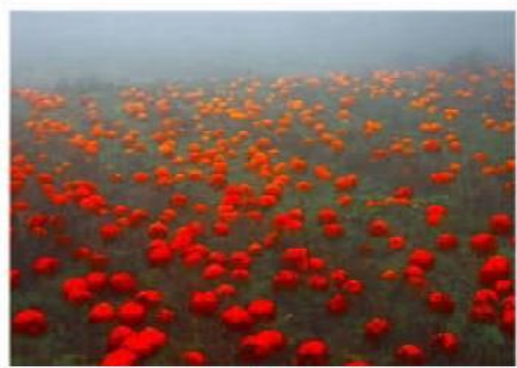

(e)

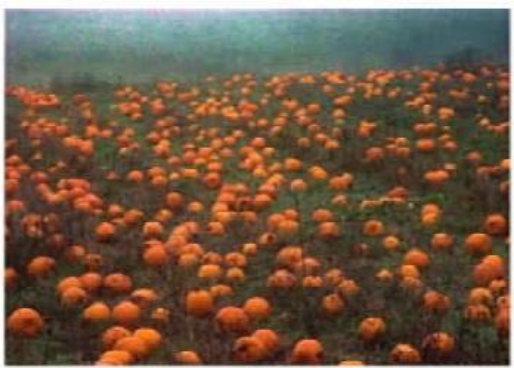

(c)

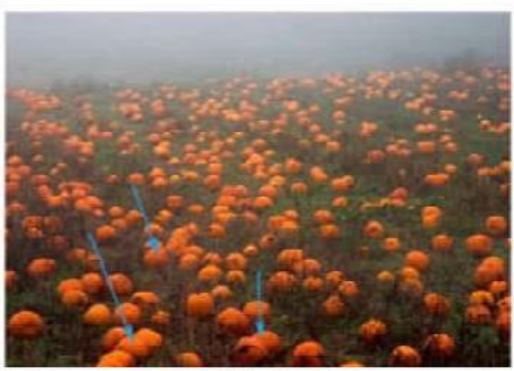

(f)

Gambar 6 Hasil Pemulihan Citra Labu dengan beragam metode dehazing. (a) citra inputan berkabut, (b) TAR, (c) DCP, (d) ADCP, (e) HGIR, (f) ACAP.

(1)

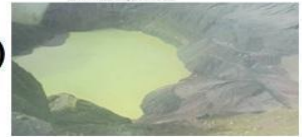

(2)

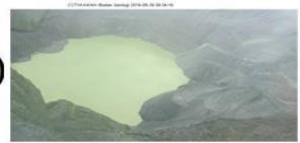

(3)

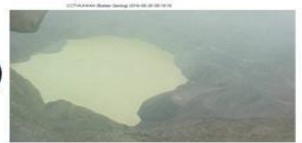

(4)

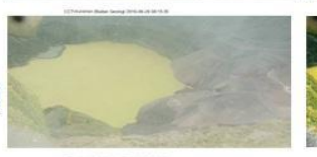

(5)

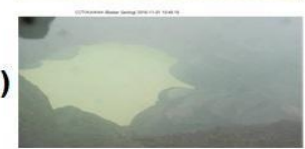

(6)

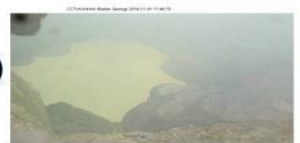

(a)
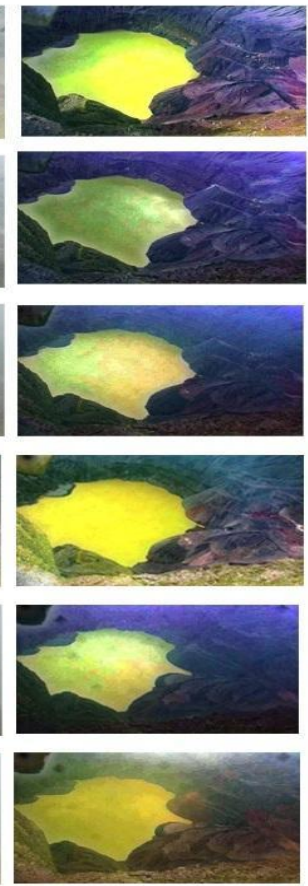

(b)
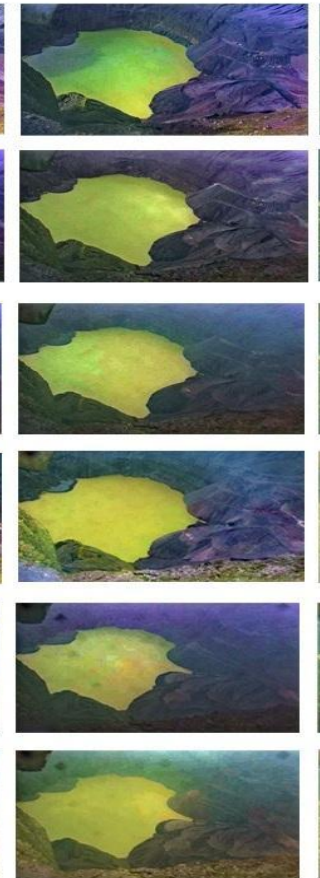

(c)
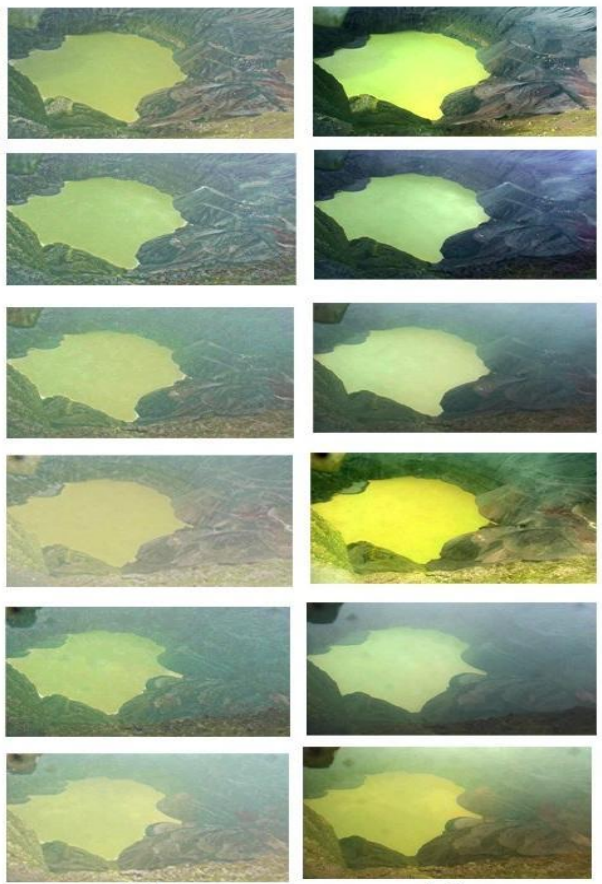

(d)

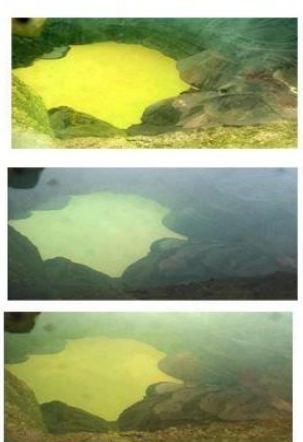

(e)

Gambar 7 Hasil Pemulihan Kabut dari citra kawah Kelud beragam metode dehazing. (a) citra inputan berkabut, (b) TAR, (c) DCP, (d) HGIR, (e) ACAP

Data simulasi yang digunakan adalah sampel citra populer yang telah banyak dipakaipada berbagai algoritma dehazing. Citra labu terlihat pada Error! Reference source not found. dibandingkan. Hasilnya Tarel mampu mengembalikan kabut yang pekat. Kontras labu di kejauhan meningkat. Tidak banyak efek halo yang ditampilkan dalam data ini. Tepi labu cenderung lebih kontras dengan warna putih. DCP juga dapat menangani kabut tebal. Tepi labu bisa diawetkan, tetapi wilayah langit mungkin gagal. Itu cenderung oversaturated, yang menghasilkan munculnya warna merah di langit. Di beberapa bagian labu, efek halo dan artefak muncul. Hasil DCP hampir mirip dengan ADCP, tetapi oversaturation di ADCP berkurang. Di HGIR, warna labu terlalu jenuh, dan kabut hanya sedikit berkurang. Sedangkan pada Error! Reference source not found. (f), ACAP dapat meningkatkan kontras warna untuk objek dekat. 
Hasil ACAP juga dibandingkan dengan citra berkabut lainnya, seperti yang ditunjukkan pada Error! Reference source not found.. PerbandinganSangat jelas bahwa warna kulit orang memiliki kontras yang tinggi, yang menghasilkan perbedaan warna yang tepat antara coklat tua dan coklat muda. Untuk orang yang jauh, DCP memberikan hasil yang lebih baik daripada ADCP tetapi tetap memberikan artefak berbentuk balok. Warna objek di ADCP dipengaruhi oleh warna global. Dengan demikian, hasil ADCP cenderung kebiruan. Sama dengan hasil labu, HGIR juga cenderung jenuh. Warna kulit dan bunga lebih kontras dari yang lainnya. Selain itu, di beberapa sisi, CAP cenderung lebih cerah. Misalnya, bagian tepi sudut jaket semakin cerah. Dalam metode yang diusulkan, warna coklat wajah hampir merata. Ini membuat warna wajah terlihat natural

\subsection{Hasil Kualitatif}

Hampir setiap algoritma dehazing mampu mendapatkan hasil yang baik dengan menghilangkan kabut pada CO. Namun, sulit untuk mengukurnya jika hanya dengan melihatnya secara sekilas. Dengan demikian, algoritma sebelumnya dibandingkan dalam kondisi cuaca yang berbeda dengan kepadatan kabut yang berbeda. Beberapa citra berisi objek terang, yang mana membuat sebagian besar algoritmadehazing rentan terhadap over-brightness. Algoritma dehazing state-of-the-art (SOTA) [3], [15], [17], [20] dibandingkan pada citra danau kawah pada Error! Reference source not found.. Error! Reference source not found. (b) - (d) adalah input citra kabut asli, hasil dari He dkk., Meng dkk., Tarel dkk. Dan akhirnya, Error! Reference source not found. (e) adalah hasil dari metode dehazing yang diusulkan Error! Reference source not found. (b) dan Error! Reference source not found. (d) menunjukkan kemampuan yang hampir sempurna untuk menghilangkan kabut, yang masing-masing dimiliki oleh He dan Tarel. Namun, hasilnya cenderung oversaturate karena warna telaga lebih cerah dibanding objek lain. Saat kabut asap semakin tebal, hasil Meng dan He cenderung kebiruan untuk daratan di sekitar danau karena dominan warna biru kehijauan. Citra danau kawah diuji menggunakan algoritma DCP. Efek halo muncul di sekitar tepi danau, seperti yang dapat kita lihat dengan jelas pada Error! Reference source not found. (2) (b), Error! Reference source not found. (3) (b), dan Error! Reference source not found. (6) (b). Fenomena halo terjadi terutama karena artefak blok dari saluran gelap itu sendiri. Efek halo ini dapat dikurangi dengan menggunakan ADCP. Sejumlah kecil bayangan, mungkin dari awan yang melewati di atas danau, tampak memantulkan permukaan air danau. Baik DCP dan ADCP meninggalkan efek kabut tebal di atas area gambar (lihat Error! Reference source not found. (6) (b) Error! Reference source not found. (6) (c). Hasil ADCP mirip dengan DCP karena pada dasarnya, Meng dkk. Melakukan improvisasi terhadap teknik DCP. Hasil serupa ini terjadi karena metode yang diusulkan dikembangkan berdasarkan CAP dalam sisi peningkatan kontras warna dengan mengurangi intensitas cahaya atmosfer pada tiap channel RGB. Di Tarel's, tepi suatu benda seperti jalur truk dan bebatuan dapat dengan jelas dilihat pada Error! Reference source not found. (1) (d) - (6) (d). Namun, Tarel's tidak dapat menangani benda tebal. Kabut Selain itu, algoritma Tarel tidak dapat menghilangkan kabut di daerah tepi kecil. Kabut tetap berada di beberapa sudut danau, seperti yang ditunjukkan pada Error! Reference source not found. (1) (d), Error! Reference source not found. (2) (d), Error! Reference source not found. (3) (d), dan Error! Reference source not found. (5) (d). Batas atas dan batas bawah untuk gamma yang dikoreksi diambil masing-masing sebagai 2,75 dan 1. Koreksi gamma tradisional mengidentifikasi bahwa nilai gamma yang lebih tinggi e berarti citra yang lebih gelap. Dan nilai gamma yang lebih rendah akan menyebabkan gambar menjadi lebih cerah. Biasanya, gamma digunakan untuk mengoreksi citra grayscale. Namun, dalam kasus kami, karena kami hanya mengoreksi peta transmisi, semakin tinggi nilai gamma yang dikoreksi menghasilkan kejenuhan di danau, dan daratan di sekitarnya akan menjadi lebih gelap.

\subsection{Hasil Evaluasi Kuesioner}

Untuk mendapatkan hasil yang lebih maksimal secara visual, kami menyebarkan kuesioner kepada sepuluh responden (RESP) untuk melakukan penilaian terhadap hasil dehazing. Pada kuesioner ini, kami hanya membandingkan hasil DCP dan ACAP karena hasil visual keduanya cukup mirip. Adapun konten dari isian ini ada tiga komponen, yaitu: warna danau, warna tepian danau, dan ketebalan kabut. Tiap-tiap pertanyaan, diberi bobot satu hingga lima di mana semakin tinggi bobot, maka semakin bagus hasilnya.

Dari penilaian warna kawah, diketahui bahwa warna danau dari citra bebas kabut dari kedua metode memiliki nilai yang sama. $80 \%$ responden memilih 4 (Baik) dan 20\% responden memilih 3 (Normal) dalam menilai warna danau yang dihasil dari kedua metode tersebut. Sehingga bisa disimpulkan bahwa warna danau pada citra bebas kabut dari kedua metode tersebut membaik dan jelas.

Dari hasil diagram kuesioner atas penilaian ketebalan kabut, penilaian RESP dalam menilai tingkat ketebalan kabut dengan metode DCP yaitu 30\% memilih 1 (Sangat Tipis), 20\% memilih 2 (Tipis), 10\% memilih 3 (Normal), 20\% memilih 4 (Tebal) dan 20\% memilih 5 (Sangat Tebal).Penilaian responden dalam menilai tingkat ketebalan kabut dengan metode Color Attenuation Prior yaitu 20\% memilih 1 (Sangat Tipis), 20\% memilih 2 (Tipis), 10\% memilih 3 (Normal), $40 \%$ memilih 4 (Tebal) dan 10\% memilih 5 (Sangat Tebal). Penilaian RESP dalam menilai tingkat ketebalan kabut dengan metode DCP yaitu 30\% memilih 1 (Sangat Tipis), 
20\% memilih 2 (Tipis), 10\% memilih 3 (Normal), 20\% memilih 4 (Tebal) dan 20\% memilih 5 (Sangat Tebal).Penilaian responden dalam menilai tingkat ketebalan kabut dengan metode Color Attenuation Prior yaitu 20\% memilih 1 (Sangat Tipis), 20\% memilih 2 (Tipis), 10\% memilih 3 (Normal), 40\% memilih 4 (Tebal) dan $10 \%$ memilih 5 (Sangat Tebal).

Dari hasil kuesioner, diperoleh data bahwa mayoritas RESP lebih memilih ACAP untuk semua komponen dengan persentase sebesar $80 \%$. Adapun secara rinci, komponen yang pertama dari sisi warna danau, RESP memberikan respon dengan nilai skor $=4$. Hasil yang memuaskan juga didapat pada komponen kedua yaitu dari sisi tepian kawah. Mayoritas juga memberikan masukkan dengan skor rata-rata 4 poin. Tak luput pula komponen terakhir juga mendapat skor yang bagus dengan rata-rata 4 poin. Sebanyak $70 \%$ RESP memberikan skor baik atau setara dengan 4 poin. Hasil kuesioner ini dapat disimpulkan bahwa terjadi perbedaan yang cukup signifikan dari penilaian RESP secara visual dengan rata-rata skor baik sebanyak 4 poin dari persentase $70 \%$ hingga $80 \%$.

\section{KESIMPULAN}

Dalam makalah ini, kami mengusulkan teknik dehazing berdasarkan CAP dan koreksi gamma. Pendekatan ini menggabungkan metode mutakhir: DCP dan CAP. Metode kami mendapatkan waktu eksekusi tercepat dibandingkan dengan algoritme sebelumnya sebesar 4,1 detik per citra. Bahkan, metode kami mencapai keunggulan dibandingkan pendekatan sebelumnya dalam pemulihan citra dari efek halo dan over saturasi yang diakibatkan warna danau yang terlalu cerah. Dari hasil ujicoba dengan data simulasi pada citra labu, ditemukan bahwa citra bebas kabut dari ACAP memiliki kontras yang lebih tinggi tanpa terjadi over saturasi sebagaimana pada hasil DCP, HGIR, dan Tarel. Kondisi over saturasi pada citra menyebabkan warna yang terlalu cerah sehingga citra tidak nampak alami. Sedangkan hasil ujicoba dengan citra kerumunan orang, juga ditemukan bahwa hasil dari metode yang diusulkan bisa menanggulangi efek halo sebagaimana yang terjadi pada DCP. Metode HGIR dari semua data simulasi, memberikan dampak efek over saturasi yang cukup signifikan. Hasil evaluasi yang terakhir, ditemukan bahwa ada perbedaan signifikan antara citra hasil DCP dengan ACAP. Mayoritas responden memberikan umpan balik yang baik pada hasil ACAP yaitu dengan rata-rata 4 poin. Pada gambar natural, beberapa scene berisi objek latar depan dan latar belakang. Metode kami gagal mempertahankan warna objek latar depan. Ini akan menjadi penelitian kami selanjutnya untuk proses dehazing dengan memisahkan objek foreground dan background agar warna foreground tetap terjaga.

\section{REFERENCES}

[1] O. V. Putra and A. Musthafa, "Dehazing Citra Kabut Gunung Berapi Kelud Dengan Color Attenuation Prior Dan Adaptive Gamma Correction," Fountain Informatics J., vol. 4, no. 2, p. 69, 2019.

[2] S. Zhao, L. Zhang, S. Huang, Y. Shen, and S. Zhao, "Dehazing Evaluation: Real-World Benchmark Datasets, Criteria, and Baselines," IEEE Trans. Image Process., vol. 29, no. XX, pp. 6947-6962, 2020.

[3] K. He, J. Sun, and X. Tang, "Single image haze removal using dark channel prior," IEEE Trans. Pattern Anal. Mach. Intell., vol. 33, no. 12, pp. 2341-2353, 2011.

[4] Q. Zhu, J. Mai, L. Shao, and S. Member, "A Fast Single Image Haze Removal Algorithm Using Color Attenuation Prior," IEEE Trans. Image Process., vol. 24, no. 11, pp. 3522-3533, 2015.

[5] E. A. Kponou, Z. Wang, and L. Li, "A Comprehensive Study on Fast Image Dehazing Techniques," Int. J. Comput. Sci. Mob. Comput., vol. 2, pp. 146-152, 2013.

[6] H. Lu, Y. Li, S. Nakashima, and S. Serikawa, "Single Image Dehazing through Improved Atmospheric Light Estimation," Multimed. Tools Appl., 2015.

[7] O. V. Putra, A. Musthafa, and F. R. Pradhana, "A Hybrid Approach on Single Image Dehazing using Adaptive Gamma Correction," J. Phys. Conf. Ser., vol. 1381, no. 1, 2019.

[8] R. T. Tan, "Visibility in Bad Weather from a Single Image," in 2008 IEEE Conference on Computer Vision and Pattern Recognition, 2008, pp. 1-8.

[9] R. Fattal, "Single Image Dehazing," ACM Trans. Graph., vol. 27, no. 3, pp. 72:1----72:9, Aug. 2008.

[10] K. He, J. Sun, and X. Tang, "Guided Image Filtering," IEEE Trans. Pattern Anal. Mach. Intell., vol. 35, no. 6, pp. 1397-1409, 2013.

[11] J. H. Kim, W. D. Jang, J. Y. Sim, and C. S. Kim, "Optimized contrast enhancement for real-time image and video dehazing," J. Vis. Commun. Image Represent., vol. 24, no. 3, pp. 410-425, 2013.

[12] M. Yang, Z. Li, and J. Liu, "Super-pixel Based Single Image Haze Removal," in 2016 Chinese Control and Decision Conference (CCDC), 2016, pp. 1965-1969.

[13] S. C. Huang, B. H. Chen, and W. J. Wang, "Visibility restoration of single hazy images captured in real-world weather conditions," IEEE Trans. Circuits Syst. Video Technol., vol. 24, no. 10, pp. 1814-1824, 2014.

[14] A. S. Parihar and G. Gupta, "A Study on Dark Channel Prior based Image Enhancement Techniques," pp. 1-7, 2020.

[15] G. Meng, Y. Wang, J. Duan, S. Xiang, and C. Pan, "Efficient Image Dehazing with Boundary Constraint and Contextual Regularization," in 2013 IEEE International Conference on Computer Vision, 2013, pp. 617-624.

[16] J. P. Tarel, N. Hautiere, L. Caraffa, A. Cord, H. Halmaoui, and D. Gruyer, "Vision Enhancement in Homogeneous and Heterogeneous Fog," IEEE Intell. Transp. Syst. Mag., vol. 4, no. 2, pp. 6-20, 2012.

[17] B. H. Chen, S. C. Huang, and F. C. Cheng, "A high-efficiency and high-speed gain intervention refinement filter for haze removal," J. Disp. Technol., vol. 12, no. 7, pp. 753-759, 2016.

[18] O. V. Putra, B. Prianto, E. M. Yuniarno, and M. H. Purnomo, "Visibility restoration of lake crater hazy image based on 
JURNAL MEDIA INFORMATIKA BUDIDARMA

Volume 5, Nomor 1, Januari 2021, Page 224-232

ISSN 2614-5278 (media cetak), ISSN 2548-8368 (media online)

Available Online at https://ejurnal.stmik-budidarma.ac.id/index.php/mib DOI 10.30865/mib.v5i1.2637

dark channel prior," in 2016 International Computer Science and Engineering Conference (ICSEC), 2016, pp. 1-6.

[19] C. H. Hsieh, Q. Zhao, and W. C. Cheng, "Single Image Haze Removal Using Weak Dark Channel Prior," 20189 th Int. Conf. Aware. Sci. Technol. iCAST 2018, no. August, pp. 214-219, 2018.

[20] J.-P. Tarel and N. Hauti, "Fast Visibility Restoration from a Single Color or Gray Level Image," in 2009 IEEE 12th International Conference on Computer Vision (ICCV), 2009, no. August 2015. 